\title{
PERANAN COGNITIVE FLEXIBILITY, SELF-ESTEEM, DAN LONELINESS TERHADAP CELEBRITY WORSHIP PADA REMAJA
}

\author{
Rahmatul Aufa ${ }^{1}$, Samsunuwiyati Mar'at ${ }^{2}$ dan Sri Tiatri ${ }^{3}$ \\ ${ }^{1}$ Program Studi Magister Psikologi, Universitas Tarumanagara Jakarta \\ Email: rahmatul.717171007@stu.untar.ac.id \\ ${ }^{2}$ Fakultas Psikologi, Universitas Tarumanagara Jakarta \\ Email: wiwimarat@gmail.com \\ ${ }^{3}$ Fakultas Psikologi, Universitas Tarumanagara Jakarta \\ Email: sri.tiatri@untar.ac.id
}

Masuk : 14-04-2019, revisi: 25-11-2019 diterima untuk diterbitkan : 26-11-2019

\begin{abstract}
ABSTRAK
Saat ini fenomena demam idola kian menyemarak di Indonesia. Semakin tinggi tingkat pengidolaan seseorang, maka semakin tinggi juga tingkat keterlibatan dengan sosok yang di idolakan. Semakin individu mengidolakan atau terlibat dengan sosok yang di idolakan maka semakin besar pula keintiman (intimacy) yang diimajinasikan terhadap sosok idola tersebut. Ketika individu menjadikan selebriti fokus utama hidupnya, maka disfungsi akan terbentuk. Beberapa individu akan membentuk hubungan khayalan dengan selebriti idola mereka dan akhirnya mengarah ke obsesi virtual terhadap selebriti idola. Obsesi inilah yang akhirnya dikenal dengan istilah celebrity worship (McCutcheon,Maltby, \& Houran, 2003). Beberapa penelitian menunjukkan celebrity worship dikaitkan dengan traits para penggemar yang patologis, negatif dan menyimpang, kinerja dan keterampilan belajar yang rendah, selfesteem yang rendah dan memiliki kesulitan dalam membentuk identitasnya, psyhological well-being yang rendah. Penelitian ini dilakukan untuk mengetahui peranan cognitive flexibility, self-esteem, loneliness, terhadap celebrity worship pada remaja. Penelitian ini menggunakan pendekatan kuantitatif dengan analisis multiple regresi. Sampel penelitian ini remaja berjumlah 630 orang dengan usia 10-24 tahun yang memiliki tokoh selebriti idola. Teknik pengambilan sampel menggunakan teknik non-probability sampling, yakni purposive sampling. Penelitian ini dilakukan dengan metode kuantitatif. yaitu dengan cara menyebar kuesioner penelitian kepada partisipan yang memenuhi kriteria. Dalam penelitian ini, peneliti mengadaptasi instrument pengumpulan data, yaitu celebrity attitude scale (CAS) 22 item, cognitive flexibility scale 12 item, Rosenberg Self Esteem Scale (RSES)10 item dan UCLA loneliness scale 20 item. Hasil penelitian ini menunjukkan adanya peranan dari cognitive flexibility, selfesteem, loneliness, usia dan jenis kelamin sebagai data demografi terhadap celebrity worship pada remaja dengan nilai $\mathrm{R}^{2}$ sebesar $12,1 \%$. Secara parsial, terdapat dua variabel yang berperan positif terhadap celebrity worship, yaitu variabel cognitive flexibility, dan variabel loneliness.
\end{abstract}

Kata Kunci: cognitive flexibility, self-esteem, loneliness, demografi

\begin{abstract}
The idol fever phenomenon is increasingly popular in Indonesia. The higher the level of one's idolization, the higher the level of involvement with the idol. The more individuals idolize or engage with idolized figures, the greater the intimacy imagined against the idol figure. When an individual makes a celebrity the main focus of his/her life, then dysfunction will form. Some individuals will form imaginary relationships with their idol celebrities which will eventually lead to virtual obsession with idol celebrities. This obsession is also known as celebrity worship (McCutcheon, Maltby, \& Houran, 2003). Several studies show celebrity worship is associated with fans' pathological, negative, and distorted traits, low performance and learning skills, low self-esteem and difficulty in forming their identities, along with low psyhological well-being. This research was conducted to determine the role of cognitive flexibility, self-esteem, and loneliness, against celebrity worship in adolescents. This research uses quantitative approach with multiple regression analysis. The sample of this study were 630 teenagers aged 10-24 years who had idols. The sampling technique uses non-probability sampling technique, namely purposive sampling. This research was conducted using quantitative methods by distributing research questionnaires to participants who meet the criteria. In this study, researchers adapted data collection instruments, which are 22 items celebrity attitude scale (CAS), 12 items cognitive flexibility scale, 10 items Rosenberg Self Esteem Scale (RSES) and UCLA loneliness scale of 20 items. The results of this study indicate the role of cognitive flexibility, self-esteem, loneliness, age and gender as demographic data on celebrity worship in adolescents with an R2 of $12.1 \%$. Partially, there are
\end{abstract}


two variables that have a positive role in celebrity worship, namely the cognitive flexibility variable, and the loneliness variable.

Keywords: cognitive flexibility, self-esteem, loneliness, demography

\section{PENDAHULUAN}

\section{Latar Belakang}

Saat ini fenomena demam idola kian menyemarak di Indonesia. Demam idola ini lebih banyak menyerang usia remaja. Fenomena demam idola dimana banyaknya penggemar adalah remaja kemungkinan tidak terlepas dari masalah perkembangan pada masa remaja. Menurut Badan Kependudukan dan Keluarga Berencana Nasional (BKKBN), rentang usia remaja adalah 10-24 tahun dan belum menikah (KEMENKES RI, 2015). Banyaknya penggemar remaja didukung oleh survei yang dilakukan oleh Kumparan terhadap 100 orang penggemar korean pop (K-pop) dan menunjukkan hasil sekitar 57 persen dari para penggemar merupakan usia remaja dan dewasa awal yakni usia 12-20 tahun serta 42 persen penggemar lainnya berusia 21-30 tahun dengan satu persen di antaranya berusia di atas 30 tahun (Kumparan, 2017). Di era globalisasi seperti saat ini, fenomena demam idola pun di dukung oleh teknologi informasi yang sangat mudah untuk diakses kapan dan dimana saja. Dengan adanya teknologi individu dapat berinteraksi dengan individu lainnya tanpa harus dibatasi oleh jarak. Individu juga akan mudah mengakses dan mengetahui informasi individu lain yang dikenal atau bahkan tidak dikenal hanya melalui teknologi. Dengan adanya teknologi, individu juga dapat mengetahui isi pemikiran orang lain bahkan keberadaan dan kondisi orang lain melalui akun media sosial seperti whatssapp, facebook, line, instagram, twitter, youtube dan lain sebagainya (Ambar, 2017).

Dengan adanya teknologi tersebut, para penggemar dapat selalu aktif untuk mencari informasi mengenai kehidupan sehari-hari dari idolanya melalui aplikasi media sosial yang mereka miliki. Penggemar tidak hanya aktif dalam mencari informasi, mereka juga aktif mengomentari, menghujat hingga mengancam penggemar selebriti lain yang memberikan respon negatif terhadap idolanya di media sosial (Mansub, 2018). Semakin tinggi tingkat pengidolaan seseorang, maka semakin tinggi juga tingkat keterlibatan dengan sosok yang diidolakan (celebrity involvement) dan semakin besar pula keintiman (intimacy) yang diimajinasikan terhadap sosok idola tersebut (Maltby, Houran, Lange, Ashe, \& McCutcheon., 2002). Beberapa individu akan membentuk hubungan khayalan dengan selebriti idola, melakukan hal apapun demi idola, bahkan dapat meniru segala hal yang berkaitan dengan idola mereka. Maltby dan Day (dalam Abraham \& Zuckerman, 2011) menunjukkan bahwa remaja dengan celebrity worship tidak hanya meniru pakaian dan gaya rambut selebriti idolanya saja, namun juga melakukan operasi kosmetik seperti selebriti idola mereka. The American Society of Aesthetic Plastic Surgery (dalam Abraham \& Zuckerman, 2011) memperkirakan bahwa dalam 10 tahun terakhir terdapat 33.000 hingga 65.000 per tahun anak di bawah usia 18 tahun melakukan operasi kosmetik. Obsesi penggemar terhadap selebriti idola inilah yang dikenal dengan istilah celebrity worship (McCutcheon,Maltby, \& Houran, 2003).

Celebrity worship merupakan bentuk dari hubungan parasosial atau satu arah yang terjadi pada penggemar dan idolanya. Mccutcheon, Ashe, Houran \& Maltby (2003) juga mendefinisikan Celebrity worship sebagai bentuk dari hubungan satu arah yang terjadi pada seseorang yang terobsesi terhadap selebriti. McCutcheon dan rekannya menunjukkan bahwa celebrity worship merupakan tipe hubungan abnormal antara penggemar dan selebriti idolanya yang terdiri dari addiction dan over-absorption. Penelitian yang mereka lakukan menjelaskan bahwa celebrity 
worship dikaitkan dengan traits para penggemar yang patologis, negatif dan menyimpang (McCutcheon, Lange, dan Houran, 2002). Traits yang patologis, negatif dan menyimpang ini ditunjukkan oleh Thompson (dalam Ang \& Chan, 2016) dimana 12 orang penggemar Michael Jackson bunuh diri karena selebriti idola mereka meninggal. Selanjutnya, Wang (dalam Ang \& Chan, 2016) juga menunjukkan salah satu penggemar (wanita) Andy Lau, rela tidak melanjutkan pendidikannya, menghabiskan uang keluarga, bahkan mengorbankan nyawa ayahnya demi mewujudkan impiannya untuk bertemu idolanya tersebut.

Maltby dan Giles (2004) mengemukakan bahwa individu yang melakukan celebrity worship memiliki psyhological well-being yang rendah. Hal ini ditunjukkan berdasarkan penelitian yang dilakukan pada 307 partisipan individu dewasa yang berasal dari UK dan menunjukkan indikasi adanya variasi yang berbeda pada disfungsi dan gejala-gejala depresi serta kecemasan pada individu dengan celebrity worship. Meskipun demikian, celebrity worship juga tidak selalu berdampak negatif. Penelitian yang dilakukan oleh Boon dan Lomore (dalam North, et.al., 2007) terhadap 75 mahasiswa yang berasal dari Kanada menunjukkan bahwa 85,7\% dari partisipan menganggap selebriti favoritnya memiliki pengaruh terhadap perilaku dan keyakinan mereka, atau telah menginspirasi mereka dalam melakukan suatu kegiatan yang positif.

Maltby dan rekannya (dalam Hua, 2015) menyusun skala celebrity worship yang terdiri dari 3 dimensi yaitu entertainment-social,intense personal, dan borderline pathological untuk membedakan apakah penggemar mengidolakan selebriti masih dalam ketertarikan yang wajar atau sudah termasuk dalam obsesi yang irasional. Dimensi pertama yaitu entertainment-social, remaja pada dimensi ini masih menunjukkan ketertarikan dan melakukan perilaku yang wajar seperti menonton, membaca dan membicarakan selebriti idola mereka ketika remaja merasa bosan dan hal yang mereka lakukan tidak sampai menganggu fungsi keseharian mereka. Selanjutnya, ketertarikan ini mulai mengarah ke obsesi ketika remaja memiliki beberapa karakteristik pada dimensi intense personal dan borderline pathological. Dimensi intense personal menggambarkan remaja yang merasa memiliki hubungan spesial dengan selebriti idola mereka, sedangkan dimensi borderline pathological menggambarkan remaja dengan fantasi dan tindakan yang tidak dapat dikendalikan demi membela selebriti idola mereka.

Perilaku dari celebrity worship yang dilakukan remaja tersebut tidak terlepas dari beberapa faktor seperti usia, jenis kelamin, cognitive flexibility, self-esteem, loneliness, usia, dan jenis kelamin. Raviv, Bar-tal dan Ben-horin (1996) menunjukkan bahwa usia merupakan salah satu faktor yang berperan terhadap perilaku celebrity worship. Puncak pemujaan terhadap idola berada pada usia remaja yaitu diantara usia 11 hingga 17 tahun dan akan semakin berkurang setelah melewati usia tersebut. Remaja yang berada di dalam usia tersebut memiliki ketertarikan untuk membangun hubungan romantis dan memiliki pasangan untuk berkencan. Faktor selanjutnya adalah jenis kelamin. Yue dan Yan (dalam Liu, 2013) mengatakan bahwa perempuan merasakan perasaan yang lebih intens terhadap selebriti idolanya dibandingkan lakilaki. Menurut McCutcheon, et.al (2002) laki-laki dan perempuan dapat menyukai idola dengan konteks yang berbeda namun intensitas untuk menyukai idola lebih tinggi di kaum perempuan. Perempuan memiliki ketertarikan terhadap seorang selebriti untuk memenuhi fantasi mereka mengenai hubungan romantis yang ideal (Raviv, Bar-tal \& Ben-horin, 1996).

Faktor selanjutnya adalah cognitive flexibility. Penelitian yang dilakukan oleh McCutcheon, Ashe, Houran dan Maltby (2003) menunjukkan bahwa cognitive flexibility berelasi negatif terhadap dimensi Intense Personal dan Borderline Pathological. Penelitian yang dilakukan oleh Maltby, Day, McCutcheon, Martin, dan Cayanus (2004) menunjukkan bahwa dimensi intense- 
personal berkaitan dengan tingkat cognitive flexibility yang rendah. Remaja yang memiliki masalah dengan citra tubuhnya dan memiliki cognitive flexibility yang rendah mungkin akan cenderung melakukan celebrity worship untuk melepaskan tekanan dari lingkungan sosialnya dengan cara mencari informasi mengenai tubuh ideal yang dimiliki oleh selebriti idolanya dan hanya akan melakukan hal-hal yang diperlihatkan oleh selebriti idolanya tersebut tanpa memikirkan cara yang lain.

Faktor lain yang berperan terhadap celebrity worship adalah harga diri atau Self-Esteem. Remaja masih dipengaruhi oleh penilaian dan evaluasi terhadap dirinya, baik secara positif maupun secara negatif. Menurut Vaughan dan Hogg (dalam Sarwono \& Meinarno, 2011) harga diri remaja yang negatif, membuat remaja akan sulit menerima penolakan sosial, untuk itu berbagai hal akan dilakukan untuk menaikkan harga dirinya. Remaja akan berusaha meningkatkan diri dengan cara melakukan celebrity worship. Remaja akan cenderung mencari dengan aktif segala informasi megenai tokoh selebriti idolanya. Mengidolakan seorang tokoh selebriti akhrinya akan membuat remaja merasa dirinya lebih berharga. Penelitian Kusuma dan Yuliawati (2013) menunjukkan bahwa terdapat korelasi negatif antara harga diri dan Celebrity worship (borderline-pathological) yaitu jika harga diri rendah maka Celebrity worship akan tinggi.

Faktor lain yang mempengaruhi terbentuknya Celebrity worship adalah Loneliness. Asche dan McCutcheon (2001) mengemukakan bahwa individu yang kesepian dan pemalu lebih tertarik pada hubungan parasosial karena hanya memiliki sedikit tuntutan sosial. Penelitian yang dilakukan oleh Asche dan McCutcheon (2001) menunjukkan adanya korelasi antara shyness, Loneliness dan Celebrity worship. Penelitian yang dilakukan oleh Dewi (2014) juga menunjukkan bahwa 85,5\% (369 dari 463 Partisipan) remaja yang berada dalam dimensi intensepersonal mengalami Loneliness. $22,5 \%$ remaja berada pada kategori Loneliness taraf rendah, $40,8 \%$ berada pada taraf sedang, dan $22,2 \%$ berada pada taraf tinggi.

Dengan demikian Tujuan yang hendak dicapai melalui penelitian ini adalah untuk mengetahui apakah cognitive flexibility, self-esteem, loneliness, usia dan jenis kelamin memiliki peranan terhadap celebrity worship pada remaja, mengetahui variabel yang berperan dalam memberikan sumbangan lebih besar terhadap celebrity worship pada remaja.

Rumusan masalah dalam penelitian ini adalah apakah cognitive flexibility, self-esteem, loneliness, usia dan jenis kelamin memiliki peranan terhadap celebrity worship pada remaja dan variabel mana yang berperan dalam memberikan peranan lebih besar terhadap celebrity worship pada remaja?

\section{METODE PENELITIAN}

\section{Partisipan, Teknik, Dan Desain Penelitian}

Partisipan dalam penelitian ini adalah remaja dari usia 10 - 24 tahun dengan jumlah 630 remaja dan belum menikah. Partisipan yang dipilih merupakan partisipan yang sedang mengidolakan satu tokoh selebriti atau lebih dan bersedia untuk mengisi kuesioner secara sukarela. Teknik pengambilan sampel menggunakan purposive sampling. Penelitian ini merupakan penelitian yang bersifat non-eksperimen karena tidak adanya manipulasi, sehingga data diperoleh dari hal yang sudah terjadi (ex post facto). Penelitian ini dilakukan dengan metode kuantitatif, yaitu dengan cara menyebar kuesioner penelitian kepada Partisipan yang memenuhi kriteria, dan data dianalisis secara kolektif untuk membuktikan hipotesis penelitian. 


\section{Pengukuran}

Variabel yang digunakan dalam penelitian ini cognitive flexibility, self-esteem, loneliness serta celebrity worship. Pengukuran variabel celebrity worship menggunakan alat ukur celebrity attitude scale (CAS) yang di adaptasi dari Stephanie (2012) dan terdiri dari 22 item. Pengukuran variabel cognitive flexibility menggunakan alat ukur cognitive flexibility scale yang diadaptasi dari teori Martin \& Rubin (1995) dan terdiri dari 12 item pernyataan. Pengukuran self-esteem menggunakan alat ukur rosenberg self esteem scale (RSES) yang diadaptasi dari Anggraeni (2018) berdasarkan teori Rosenberg (1965) dengan jumlah 10 item. Pengukuran loneliness menggunakan alat ukur UCLA loneliness scale yang diadaptasi dari Armen (2017) berdasarkan teori Russel \& Cotrona (1988) dan terdiri dari 20 item pernyataan.

\section{HASIL DAN PEMBAHASAN}

Partisipan penelitian ini berjumlah 630 remaja dengan rentang usia 10 sampai dengan 24 tahun. Berdasarkan data pada tabel 1 dapat dilihat bahwa partisipan penelitian ini di dominasi oleh jenis kelamin perempuan dengan persentase $83,5 \%$. Partisipan yang paling banyak dalam penelitian ini berada pada usia 18 tahun dengan jumlah 83 orang $(13,2 \%)$ dan paling sedikit berada pada usia 11 tahun dengan jumlah 2 orang $(0,3 \%)$. Selanjutnya, penelitian ini di dominasi oleh partisipan yang sedang menempuh pendidikan kuliah dengan jumlah 327 orang (51,9\%). Partisipan yang sedang menempuh pendidikan sekolah merupakan partisipan paling sedikit dengan jumlah 5 orang $(0,8 \%)$. Partisipan pada penelitian ini juga didominasi oleh mahasiswa dengan jumlah sebanyak 331 orang $(52,5 \%)$. Partisipan yang ikut serta dalam komunitas atau fanbase penggemar selebriti yang diidolakan berjumlah 302 orang dengan persentase sebesar 47,9\% dan partisipan yang tidak ikut serta dalam komunitas atau fanbase berjumlah 328 orang.

Tabel 1. Deksripsi Umum Partisipan Penelitian

\begin{tabular}{|c|c|c|c|c|c|}
\hline No. & Kategori & Jenis Kelamin & Frekuensi & Persentase & Total \\
\hline \multirow[t]{2}{*}{1} & Jenis Kelamin & Laki-laki & 104 & 16,5 & 630 \\
\hline & & Perempuan & 526 & 83,5 & \\
\hline \multirow[t]{15}{*}{2} & Usia (tahun) & 10 & 5 & 0,8 & 630 \\
\hline & & 11 & 2 & 0,3 & \\
\hline & & 12 & 15 & 2,4 & \\
\hline & & 13 & 46 & 7,3 & \\
\hline & & 14 & 68 & 10,8 & \\
\hline & & 15 & 39 & 6,2 & \\
\hline & & 16 & 24 & 3,8 & \\
\hline & & 17 & 54 & 8,6 & \\
\hline & & 18 & 83 & 13,2 & \\
\hline & & 19 & 61 & 9,7 & \\
\hline & & 20 & 73 & 11,6 & \\
\hline & & 21 & 59 & 9,4 & \\
\hline & & 22 & 51 & 8,1 & \\
\hline & & 23 & 35 & 5,6 & \\
\hline & & 24 & 15 & 2,4 & \\
\hline \multirow[t]{5}{*}{3} & Pendidikan Saat Ini & SD & 5 & 0,8 & 630 \\
\hline & & SMP/MTS & 148 & 23,5 & \\
\hline & & SMA/MAN/SMK & 107 & 17,0 & \\
\hline & & Kuliah & 327 & 51,9 & \\
\hline & & Lainnya & 43 & 6,8 & \\
\hline 4 & Pekerjaan & Pelajar & 238 & 37,8 & 630 \\
\hline
\end{tabular}




\begin{tabular}{|c|c|c|c|c|c|}
\hline \multirow{4}{*}{5} & & Mahasiswa & 331 & 52,5 & \multirow{4}{*}{630} \\
\hline & \multirow{3}{*}{$\begin{array}{l}\text { Ikut Serta Dalam } \\
\text { Komunitas }\end{array}$} & Lainnya & 61 & 9,7 & \\
\hline & & Iya & 302 & 47,9 & \\
\hline & & Tidak & 328 & 52,1 & \\
\hline
\end{tabular}

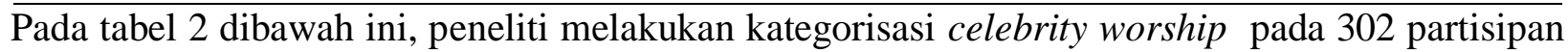
yang ikut serta dalam komunitas selebriti dan didapatkan hasil bahwa pada penelitian ini, remaja yang ikut serta dalam komunitas berada pada kategori celebrity worship dengan kategori sedang dan dengan persentase $68,5 \%$.

Tabel 2. Kategorisasi Celebrity Worship

\begin{tabular}{ccrr}
\hline Total Partisipan & Kategorisasi & $\begin{array}{r}\text { Jumlah } \\
\text { Partisipan }\end{array}$ & Persentase \\
\hline \multirow{3}{*}{302 orang } & $\mathrm{X}<\mathrm{M}-1 \mathrm{SD}$ (Rendah) & 42 & 13,9 \\
& $\mathrm{M}-1 \mathrm{SD} \leq \mathrm{X} \leq \mathrm{M}+1 \mathrm{SD}$ & 207 & 68,5 \\
& (Sedang) & 95 & 17,5 \\
\hline
\end{tabular}

Keterangan: $\mathrm{X}=$ Mean, $\mathrm{M}=$ Median, $\mathrm{SD}=$ Standar Deviasi

Pada tabel 3 dibawah ini menunjukkan hasil uji regresi dari keseluruhan IV terhadap DV dari jumlah 302 partisipan yang ikut serta dalam komunitas, didapatkan nilai $\mathrm{R}$ sebesar 0,361 dan koefisien determinasi $R$ square adalah sebesar 0,130. Hasil ini menunjukkan bahwa keseluruhan independent variabel (cognitive flexibility, self-esteem, loneliness, usia dan jenis kelamin) bersama-sama memberikan sumbangan peranan terhadap dependent variabel yaitu celebrity worship sebesar $13 \%$ dan sisanya $87 \%$ di pengaruhi oleh variabel lain.

Tabel 3. Summary Uji Regresi Keseluruhan IV Terhadap DV

\begin{tabular}{ccccc}
\hline Variabel Prediktor & R & R Square & F & Sig \\
\hline CF,SE,LN,Usia,JK & $.361 \mathrm{a}$ & .130 & 8.852 & $.000 \mathrm{~b}$ \\
\hline
\end{tabular}

Pada tabel 4 dapat dilihat sumbangan dari setiap IV terhadap DV dari jumlah 302 orang dan ikut serta dalam komunitas. Dapat disimpulkan dari data tabel tersebut bahwa dari lima independent variabel (cognitive flexibility, self-esteem, loneliness, usia dan jenis kelamin) yang memiliki peranan positif terhadap celebrity worship hanya dua variabel, yaitu variabel cognitive flexibility dan loneliness.

Tabel 4. Summary Sumbangan Masing-Masing IV Terhadap DV

\begin{tabular}{lccccc}
\hline Variabel Prediktor & $\mathbf{R}$ & R Square & $\mathbf{F}$ & Sig & Beta \\
\hline Cognitive flexibility & .213 & .045 & 14,279 & .000 & .352 \\
Self-esteem & .267 & .071 & 11,481 & .065 & -.132 \\
Loneliness & .360 & .130 & 14,813 & .000 & .255 \\
Usia & .360 & .130 & 11,079 & .898 & .007 \\
Jenis Kelamin & .361 & .130 & 8,852 & .773 & .016 \\
\hline
\end{tabular}

Hasil penelitian ini menunjukkan bahwa variabel cognitive flexibility berperan positif terhadap celebrity worship dengan nilai beta sebesar $35,2 \%$, Artinya, semakin tinggi fleksibilitas remaja maka celebrity worship nya juga tinggi. Hasil penelitian ini tidak sesuai dengan penelitian yang dilakukan oleh Maltby, Day, McCutcheon, Martin,dan Cayanus (2004) yang menunjukkan bahwa dimensi intense-personal berkaitan dengan tingkat Cognitive flexibility yang rendah. Penelitian yang dilakukan oleh McCutcheon, Ashe, Houran \& Maltby (2003) juga menunjukkan bahwa cognitive flexibility berelasi negatif terhadap dimensi Intense Personal dan Borderline 
Pathological. Perbedaan ini mungkin dapat dikaitkan dengan adanya korelasi antara cognitive flexibility dan loneliness. Remaja pada penelitian ini tetap melakukan celebrity worship karena perasaan sepi yang mereka hadapi. Ketika remaja merasa kesepian, maka mereka akan mengalihkan perasaan sepi itu dengan membaca, menonton, mendengarkan atau mengakses akun selebriti idola mereka. Celebrity worship juga memiliki dampak positif. Penelitian yang dilakukan oleh Boon dan Lomore (dalam North et al., 2007) menunjukkan bahwa partisipan menganggap selebriti favoritnya memiliki pengaruh terhadap perilaku dan keyakinan mereka, atau telah menginspirasi mereka dalam melakukan suatu kegiatan yang positif dan mungkin. Oleh karena itu, dengan mengakses informasi mengenai selebriti idola mereka remaja dapat mengalihkan perasaan kesepian mereka.

Variabel selanjutnya adalah Self-Esteem. Variabel Self-Esteem memiliki nilai beta sebesar 13,2\% dan tidak memberikan peranan terhadap celebrity worship pada remaja. Hasil penelitian ini tidak sesuai dengan penelitian Kusuma dan Yuliawati (2013) yang menunjukkan bahwa terdapat korelasi negatif antara harga diri dan Celebrity worship (borderline-pathological) yaitu jika harga diri rendah maka Celebrity worship akan tinggi. Variabel self-esteem tidak memiliki peranan terhadap celebrity worship mungkin karena partisipan pada penelitian ini merupakan partisipan yang ikut serta dalam komunitas selebriti idola. Eksperimen yang dilakukan di Belanda oleh Baaren dan koleganya (dalam Myers, 2012) mengindikasikan bahwa peniruan remaja terhadap lingkungannya akan membuat lingkungan menerima remaja tersebut dan menyukainya. Jika teman mengidolakan seorang selebriti sebagai tokoh idolanya maka remaja yang sering mendapatkan informasi dari temannya mengenai tokoh idola temannya dapat mendorong remaja untuk ikut menyukai tokoh idola tersebut.

Variabel selanjutnya yang berperan positif terhadap celebrity worship pada remaja adalah variabel loneliness dengan nilai beta sebesar 25,5\%. Hasil ini sesuai dengan pendapat Asche dan McCutcheon (2001) yang mengemukakan bahwa individu yang kesepian dan pemalu lebih tertarik pada hubungan parasosial karena hanya memiliki sedikit tuntutan sosial. Penelitian yang dilakukan oleh Dewi (2014) juga menunjukkan bahwa 85,5\% (369 dari 463 Partisipan) remaja yang berada dalam dimensi intense-personal mengalami Loneliness. Pada penelitian ini ketiga dimensi celebrity worship berpengaruh signifikan terhadap celebrity worship dan jika dilihat dari arahnya yang positif menunjukkan semakin tinggi loneliness maka ketiga dimensi celebrity worship juga semakin tinggi. Remaja masih belum mampu mengelola waktu yang mereka miliki. Mereka memiliki kesibukan ketika mereka berada dalam lingkungan sekolah saja (Santrock, 2011). Namun ketika mereka telah menyelesaikan kegiatan di sekolah maka mereka akan merasa kesepian karena tidak memiliki kesibukan lainnya.

Secara demografis, variabel usia tidak memiliki peranan terhadap celebrity worship dengan nilai beta sebesar 0,7\%. Penelitian ini tidak sesuai dengan yang dikemukakan oleh Raviv et.al (1996) bahwa celebrity worship akan benar-benar berhenti pada saat individu memasuki dewasa awal dan akan berkurang sesuai dengan bertambahnya usia karena dengan bertambahnya usia seharusnya identitas diri sudah dipertajam, mencapai autonomi dan mereka juga sudah mulai merubah minat dan tujuan hidup. Usia remaja yang menuju dewasa dan masih melakukan celebrity worship mungkin bisa disebabkan oleh tahapan pencarian dan pembentukan identitas diri yang belum selesai dan kemungkinan juga karena partisipan penelitian ini melakukan celebrity worship hanya untuk mengalihkan kesepian saja. Variabel jenis kelamin juga tidak memiliki peran terhadap celebrity worship dengan nilai beta 1,6\%. Hal ini sesuai dengan pendapat McCutcheon, et.al (2002) dimana laki-laki dan perempuan sama-sama menyukai idola namun dengan konteks yang berbeda. 


\section{KESIMPULAN DAN SARAN}

Kesimpulan yang dapat diambil dari penelitian ini adalah "terdapat peranan variabel cognitive flexibilty, self-esteem, loneliness, usia, jenis kelamin, terhadap terbentuknya celebrity worship pada remaja" dengan nilai sumbangan sebesar $12,1 \%$ dan sisanya sebesar $87,9 \%$ yang dipengaruhi oleh variabel lain diluar penelitian ini. Dengan demikian, jika dilihat dari keseluruhan maka hipotesa pada penelitian ini terbukti. Secara parsial, hanya 4 variabel yang berperan terhadap celebrity worship pada remaja yaitu cognitive flexibility, loneliness, usia dan jenis kelamin. Selanjutnya berdasarkan remaja yang ikut serta dalam komunitas, hasil uji regresi menunjukkan bahwa keseluruhan independent variabel (cognitive flexibility, self-esteem, loneliness, usia dan jenis kelamin) bersama-sama memberikan sumbangan peranan terhadap dependent variabel yaitu celebrity worship sebesar 13\% dan sisanya $87 \%$ di pengaruhi oleh variabel lain. Secara parsial, hanya 2 variabel yang berperan terhadap celebrity worship pada remaja yaitu cognitive flexibility, dan loneliness.

Untuk perkembangan penelitian selanjutnya disarankan kepada peneliti yang tertarik dan berminat pada persoalan yang sama untuk menambah variabel lain yang mungkin memiliki pengaruh yang lebih besar terhadap celebrity worship. Kemudian mengambil sampel dengan kriteria mengidolakan selebriti dalam kurun waktu yang lama. Range usia partisipan sebaiknya juga diusahakan sama banyak. Peneliti lebih lanjut juga dapat menggunakan metode mix method agar lebih menunjang tujuan penelitian. Selain itu, peneliti selanjutnya juga dapat memberikan intervensi kepada partisipan dengan kategori celebrity worship tinggi dari variabel yang berperan signifikan dalam membentuk celebrity worship pada remaja. Bagi pihak keluarga, guru serta orang-orang yang berada dilingkungan partisipan agar lebih aware terhadap kehidupan remaja tersebut. Bagi remaja sendiri, diharapkan untuk mengisi waktu luang atau mengikuti perkumpulan yang lebih bermanfaat dan agar lebih bijak lagi dalam menggunakan teknologi sehingga tidak membentuk hubungan parasosial. Hasil menunjukkan dimensi intense personal berkaitan dengan kesehatan mental dimana remaja akan berempati secara berlebihan kepada selebriti idolanya. Diharapkan kepada orang-orang yang berada di lingkungan remaja tersebut untuk selalu mengingatkan bahwa empati itu tidak salah asalkan tidak berlebihan.

\section{Ucapan Terima Kasih (Acknowledgement)}

Penulis mengucapkan terimakasih kepada seluruh partisipan penelitian yang telah bersedia meluangkan waktu untuk mengisi kuesioner penelitian di sela kesibukannya. Juga ucapan terima kasih kepada semua pihak yang telah membantu penelitian ini.

\section{REFERENSI}

Abraham, A. A., \& Zuckerman, D. (2011). Adolescents, celebrity worship, and cosmetic surgery. Journal of Adolescent Health, 49(5), 453-4. DOI: 10. 1016 /j.jado health. 2011.08.014. Source: PubMed.

Ambar. (2018). (2019, April 10). 4 pengaruh media sosial dalam komunikasi dan penjelasan lengkap. Pakar Komunikasi. https://pakarkomunikasi.com/ pengaruh-media-sosial

Anggraeni, U. (2018). Efektivitas pelatihan keterampilan komunikasi untuk meningkatkan selfesteem pada siswa flight operation officer training center $X$ di Jakarta (Tesis). Universitas Tarumanagara, Jakarta.

Ang, C. S., \& Chan, N. N. (2016). Adolescents' views on celebrity worship: A qualitative study. Journal of current psychology, 37(1), 139-148. DOI: 10.1007/s12144-016-9497-0 
Armen, E. (2017). Penerapan art therapy untuk mengatasi loneliness pada lansia yang tidak pernah dikunjungi keluarganya (studi pada panti X) (Tesis). Universitas Tarumanagara, Jakarta.

Asche, D., \& Mccutcheon., Lynn E. (2001). Shyness, loneliness, and attitude toward celebrities. Journal current research in social psychology, 6(9).

Dewi, A. T. (2014). Pengaruh loneliness \& shyness terhadap celebrity worship pada remaja (Skripsi). Universitas Tarumanagara, Jakarta.

Giles, D. C., \& Maltby, J. (2004). The role of media figures in adolescent development: Relations between autonomy, attachment, and interest in celebrities. Personality and Individual Differences, 36(4), 813-822. http://dx.doi.org/10.1016/S0191-8869(03)001545

Hua, P. (2015, Februari 1). Teen idol-when does a celebrity crush become an obsession?. The Kids Are All Right. http://www.thekidsareallright.com.au/2015/healthandwellbeing/teenidol-celebrity-worship-one-direction/

Kementerian Kesehatan RI. (2015). Situasi kesehatan reproduksi remaja. Pusat Data dan Informasi.

http://www.depkes.go.id/resources/download/pusdatin/infodatin\%20reproduksi\%20remaj a-ed.pdf

Kumparan. (2017, Januari 6). Fanatisme fans k-pop: Candu dan bumbu remaja. https://kumparan.com/@kumparank-pop/fanatisme-fans-k-pop-candu-dan-bumbu-remaja

Kusuma, L., \& Yuliawati, L. (2013). Self-esteem and celebrity worship on late adolescents. Anima Indonesian Psychological Journal, 28(4), 202-209.

Liu, J. K. K. (2013). Idol worship, religiosity, and self-esteem among university and secondary students in Hong Kong. Discovery-SS Student E-journal 2, 15-28.

Maltby, J., Houran, J., Lange, R., Ashe, D., \& McCutcheon, L. E. (2002). Thou shalt worship no other gods-unless they are celebrities: The relationship between celebrity worship and religious orientation. Personality and Individual Differences, 32(7), 1157-1172. http://dx.doi.org/10.1016/S0191-8869(01)00059-9

Maltby, J., Day, L., McCutcheon, L. E., Martin, M. M., \& Cayanus, J. L. (2004). Celebrity worship, cognitive flexibility, and social complexity. Personality and Individual Differences, 37, 1475-1482. doi:10.1016/j.paid.2004.02.004

Mansub. (2018). Maraknya Komentar Jahat di Media Sosial. https://student.cnnindonesia.com/edukasi/20171229090331-445-265417/maraknyakomentar-jahat-di-media-sosial/

McCutcheon, L. E., Lange, R., \& Houran, J. (2002). Conceptualization and measurement of celebrity worship. The British Psychological Society, 93(1), 67-87.

McCutcheon, L. E., Ashe, D. D., Houran, J., \& Maltby, J. (2003). A cognitive profile of individuals who tend to worship celebrities. Journal of Psychology, 137(4), 309-322.

Martin, Matthew \& Rubin, Rebecca. (1995). A new measure of cognitive flexibility. Psychological Reports, 76(2), 623-626. DOI: 10.2466/Pr0.1995.76.2.623

North, A. C., Sheridan, L., Maltby, J., \& Gillett, R. (2007). Attributional style, self-esteem, and $\begin{array}{llll}\text { celebrity } \quad \text { worship. Media } & \text { Psychology, } & \text { 9(2), } & \text { 291-308. }\end{array}$ http://dx.doi.org/10.1080/15213260701285975

Raviv, A., Bar-Tal, D., Raviv, A., \& Ben-Horin, A. (1996). Adolescent idolization of pop singers: Causes, expressions, and reliance. Journal of Youth and Adolescence, 25, 631650.

Rosenberg, M., Scoenbach, C., Schooler, C., \& Rosenberg, F. (1995). Global self-esteem and specific self esteem: Different concepts, different outcomes. American Sociological Review, 60(1), 141-156. http://www.campus.fsu.edu/xid-267778004 
Sarwono, S. W., \& Meinarno. E. A. (2011). Psikologi sosial. Jakarta: Penerbit Salemba Humanika.

Stephani, J. (2012). Hubungan antara attachment dan celebrity worship pada remaja puteri penggemar selebriti Korea (Skripsi). Universitas Tarumanagara, Jakarta. 